\title{
RADIOCARBON DATING OF SEDIMENTS
}

\section{ALISON J FOWLER, RICHARD GILLESPIE* and ROBERT E M HEDGES}

Research Laboratory for Archaeology and the History of Art Oxford University, 6 Keble Road, Oxford OX1 3QJ, England

\section{INTRODUCTION}

In ${ }^{14} \mathrm{C}$ dating of sediment, the date of deposition is associated with its ${ }^{14} \mathrm{C}$ age. Most sediments are complex mixtures containing little organic material frequently derived from several sources. The most conspicuous sources of error result from 1) the incorporation of "fossil" carbon (eg, graphite, lignite, etc) into a more recent sediment. This is particularly important in low carbon sediments (Olsson, 1972); 2) the incorporation of older, 'reworked' sedimentary material, eg, from terrigenous sources into a lacustrine environment (Schoute, Mook \& Streuerman, 1983); 3) the dating of mainly autochthonous material which has metabolized carbon from dissolved bicarbonate carbonates originating from dissolution of fossil.

To provide more information for the ${ }^{14} \mathrm{C}$ ages of components of a sediment, we have used the small sample capability ( $i e,>=1 \mathrm{mg}$ carbon) of the Oxford Radiocarbon Accelerator to date specific fractions. Within the limitations of the 'conventional' method, different fractions in soils have been the subject of two investigations (Scharpenseel, 1979; Sheppard, Syed \& Mehringer, 1979). In general the results show that a measurement on undifferentiated sediment may lead to serious errors in the ${ }^{14} \mathrm{C}$ date, that specific fractions do not guarantee a better date for deposition, but nearly always provide valuable information on the particular history of the individual sediment in relation to its specific context. It is usually possible to estimate the occurrence of the first two sources of error listed above, but more difficult to quantify the extent of terrestrial input and "hard water" error.

\section{SEDIMENT ORGANIC CHEMISTRY}

Table 1 shows the typical distribution of sediments.

The preparation scheme for various components of sedimentary organic matter used in this study is given in Table 2.

In many ways lipids would seem to offer the most promise for dating, because of their greater specificity (both in terms of chemical characterization and source assignment, see below) and because of their comparative lack of mobility.

Analyses of sedimentary lipids (of ${ }^{14} \mathrm{C}$ age) give the distribution shown in Table 3 .

Unfortunately, polar lipids, which are relatively unspecific in origin, comprise the bulk of the lipid fraction in most cases. This puts inconveniently stringent requirements on small sample dating capability.

Further analysis of the lipid molecular classes is possible by gas liquid chromatography, and allows the detection of specific "marker" compounds indicating higher plant or algal origin. Some examples are shown in

* Present address: Dept of Physics, University of Arizona, Tucson 
TABLE 1

Approximate composition of sedimentary organic matter

\begin{tabular}{lc}
\hline Molecular type & \% Dry weight \\
\hline Humic and fulvic acids & $30-60$ \\
Cellulose & $5-20$ \\
Lipids & 1 \\
Amino acids & $<1$ \\
Other & $10-50$ \\
\hline
\end{tabular}

Table 4. Only in exceptional circumstances, however, would a sufficient quantity of such a marker compound be available for ${ }^{14} \mathrm{C}$ dating. Thus, information derived from lipid analysis in conjunction with measured ages of sedimentary fractions helps estimate the reliability of the ages in relation to the possible date of sedimentation, and to identify possible sources of error that have long been cited but rarely demonstrated.

\section{RESULTS}

\section{Evidence for Fossil Age Carbon}

The inclusion of carbon of this type is mainly a source of uncertainty in the measured ages of samples from newly deglaciated terrain. The most dramatic evidence for this was obtained from a sample of Late Glacial clay from the Llyn Gwernan site (Fig 1) and from the Vuolconjavvi, Finland, site (Fig 2). The chlorite-treated sample, namely that which contains no organic matter except any residual cellulose and no acid-soluble carbonate, is shown to be much older than any of the other components for both samples. The only major source of carbon remaining in these samples must be graphite, coal, and/or carbon-bearing rock flour. The presence of "dead" fossil carbon becomes more important in those sediments containing very low total carbon. Such sediments are more likely to be submitted for dating with the increase in small sample dating facilities.

\section{Evidence for Terrestrial Inwash}

${ }^{14} \mathrm{C}$ dating of sediments cannot generally identify terrestrial inwash to a lake unless a sudden and major change in the amount of terrestrial input occurs, the most common example being the mobilization of top soil during forest clearance, which manifests itself as an inversion in the dating of a lake core. Lipid analysis may indicate a major higher plant input, suggesting a significant contribution to the sedimentation from terrestrial sources. However, samples from a highly productive lake in central Mexico (Lake Zacapu, Fig 3) illustrate a change in input by comparison of the measured ages of the 'conventional preparation' and the first crude lipid extract. The sample at 870 to $880 \mathrm{~cm}$ depth from the top of the core is strikingly divergent from the roughly parallel trend of the two measured ages. Hard water (see below) is proposed as the reason for the age differences down the sedimentary column, and superimposed on top of that is a changing amount of 


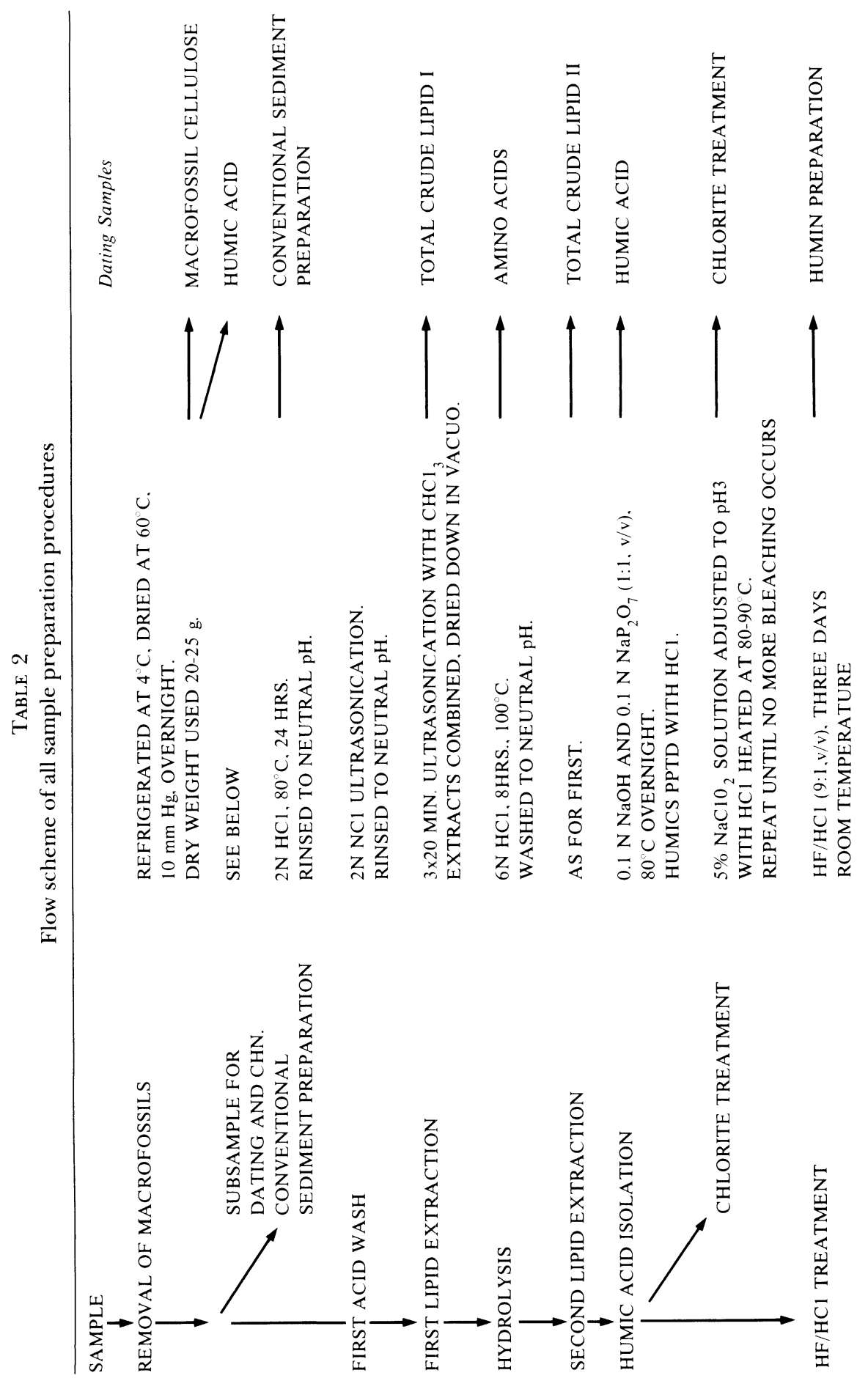


TABLE 3

Approximate \% of lipid molecular classes found in sediments

\begin{tabular}{lr}
\hline Molecular class & $\%$ \\
\hline Polar lipids & 83 \\
Sterols & 1 \\
Pigments & 3 \\
Alcohols & 2 \\
Fatty acids & 5 \\
Other & 5 \\
\hline
\end{tabular}

terrestrial inwash. The 870 to $880 \mathrm{~cm}$ sample has a much higher algal component (found by gas-chromatographic analysis of extracted lipids (Table 4)) in the lipid samples analyzed than the sediment samples above it. Since the lake has always been highly productive (the sediment is diatomaceous), this is interpreted not as a change in lake primary productivity but

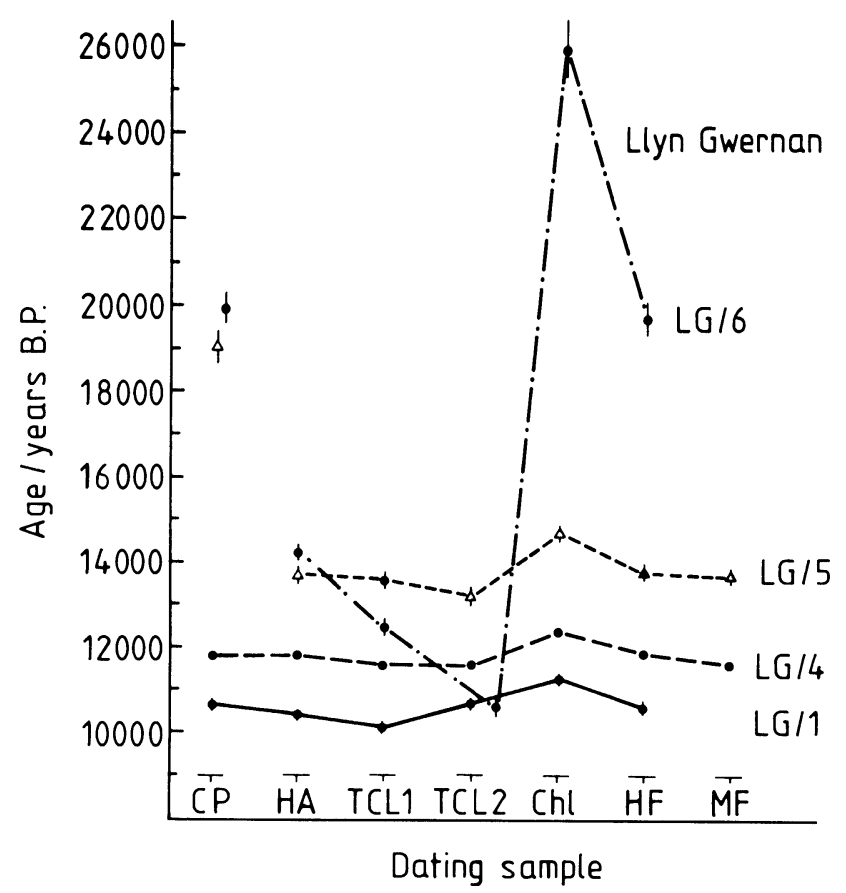

Fig 1. Dates for the various components from different stratigraphic levels of sediment from Llyn Gwernan

$\mathrm{CP}-$ conventional preparation

HA-humic acid

TCL1 - total crude lipid extract

TCL2 - extract of bound crude lipid

CH1 - "cellulose" extract from treatment with sodium chlorite

$\mathrm{HF}$ - extract after treatment with $\mathrm{HF} / \mathrm{CH} 1$

$\mathrm{MF}$ - macrofossils after chlorite treatment 
TABLE 4

Marker molecules used with values for approximate \% composition

\begin{tabular}{|c|c|c|c|c|}
\hline $\begin{array}{l}\text { Marker } \\
\text { molecule }\end{array}$ & Algae & $\begin{array}{c}\text { Source } \\
\text { (higher plants) }\end{array}$ & Bacteria & Reference \\
\hline $\mathrm{N}$-alkanes & $\begin{array}{l}\text { Carbon chain length } \\
\quad-17,19\end{array}$ & $-27,29,31,33,35$ & & Cranwell (1973) \\
\hline $\begin{array}{l}1 \% \text { total } \\
\text { crude lipid }\end{array}$ & $5 \%$ of n-alkanes & $30 \%$ of n-alkanes & & $\begin{array}{l}\text { Brooks et al } \\
\quad(1976)\end{array}$ \\
\hline N-fatty acids & $5 \%-12,14,16,18$ & $-22,24,26,28,30$ & & Cranwell (1974) \\
\hline $\begin{array}{l}2 \% \text { total } \\
\text { crude lipid }\end{array}$ & $40 \%$ of n-fatty acids & $\begin{array}{l}40 \% \text { of n-fatty } \\
\text { acids }\end{array}$ & & $\begin{array}{l}\text { Boon, de Leeuw } \\
\text { \& Schenck } \\
(1975)\end{array}$ \\
\hline $\begin{array}{l}\text { Branched } \\
\text { fatty acids }\end{array}$ & & & $\begin{array}{l}\text { Iso and anteiso } \\
15,16,17,18\end{array}$ & $\begin{array}{l}\text { Brooks et al } \\
\quad(1977)\end{array}$ \\
\hline $\begin{array}{l}1 \% \text { total } \\
\text { crude lipid }\end{array}$ & & & $\begin{array}{l}10 \% \text { of } \\
\text { branched fatty } \\
\text { acids }\end{array}$ & \\
\hline
\end{tabular}

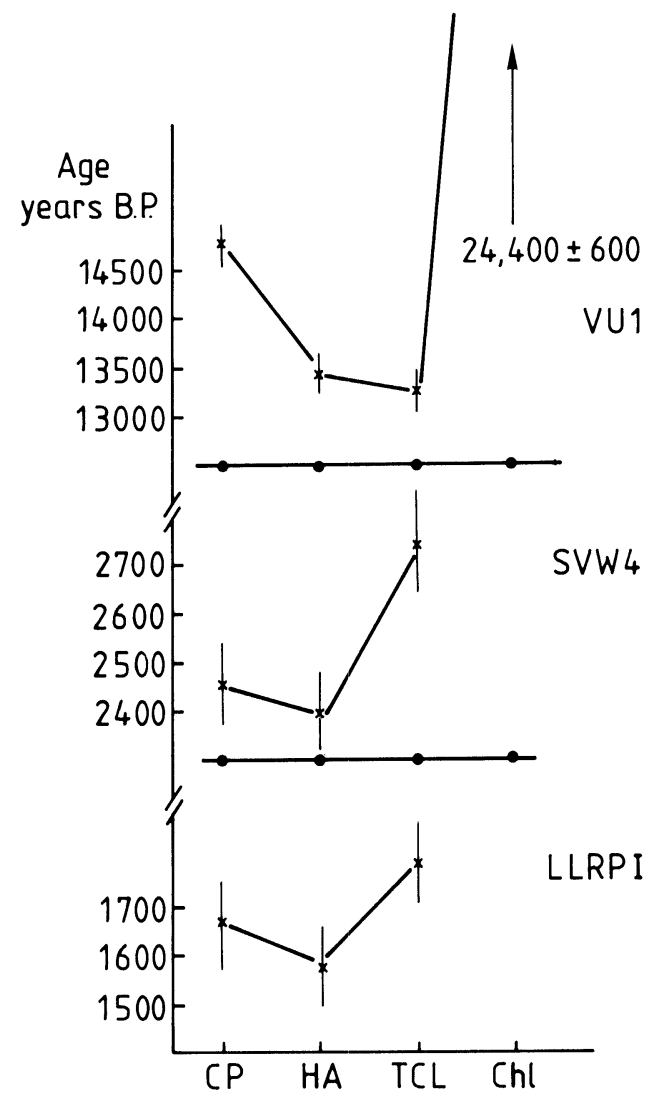

Fig 2. Dates for the various components from one sample each from sediment from Vuolconjavvi (Finland), Svinavatu (Iceland), and Loch Lomond (Scotland). Labels for each component as for Figure 1. 
Age / years B.P.

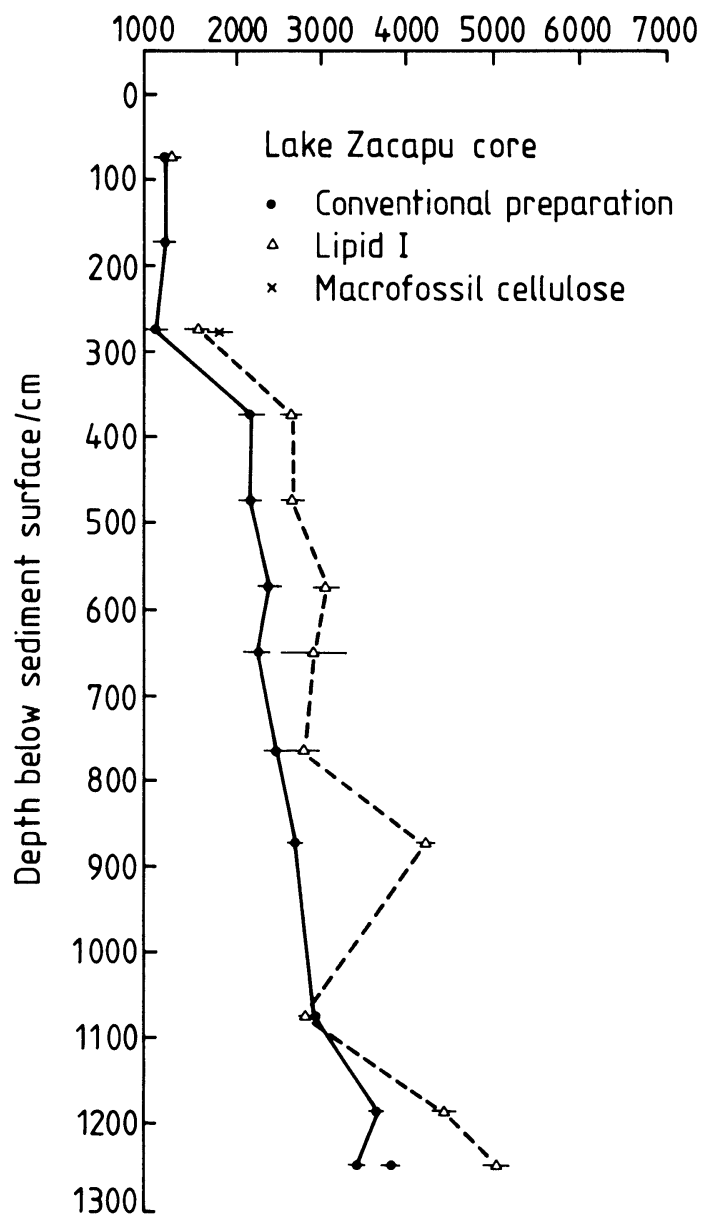

Fig 3. A comparison of dates from the conventional preparation and from the first lipid extract from a series of sediment samples from Lake Zacapu

as a decrease in terrestrial input, presumably due to a drier period with less precipitation and run-off.

\section{Evidence for Hard-Water Error}

Hard-water error tends to make the measured ages too old, eg, the lipid results for Lake Zacapu (Fig 3), due to the incorporation of carbon from dissolved carbonate not in equilibrium with the atmosphere and derived from dissolution of fossil soil carbonate at the time of deposition. Lake Zacapu is an alkaline lake and carbonate deposits have been found in the sediments.

The second lipid extract of the Shewalton Moss peat sample SM3 also 


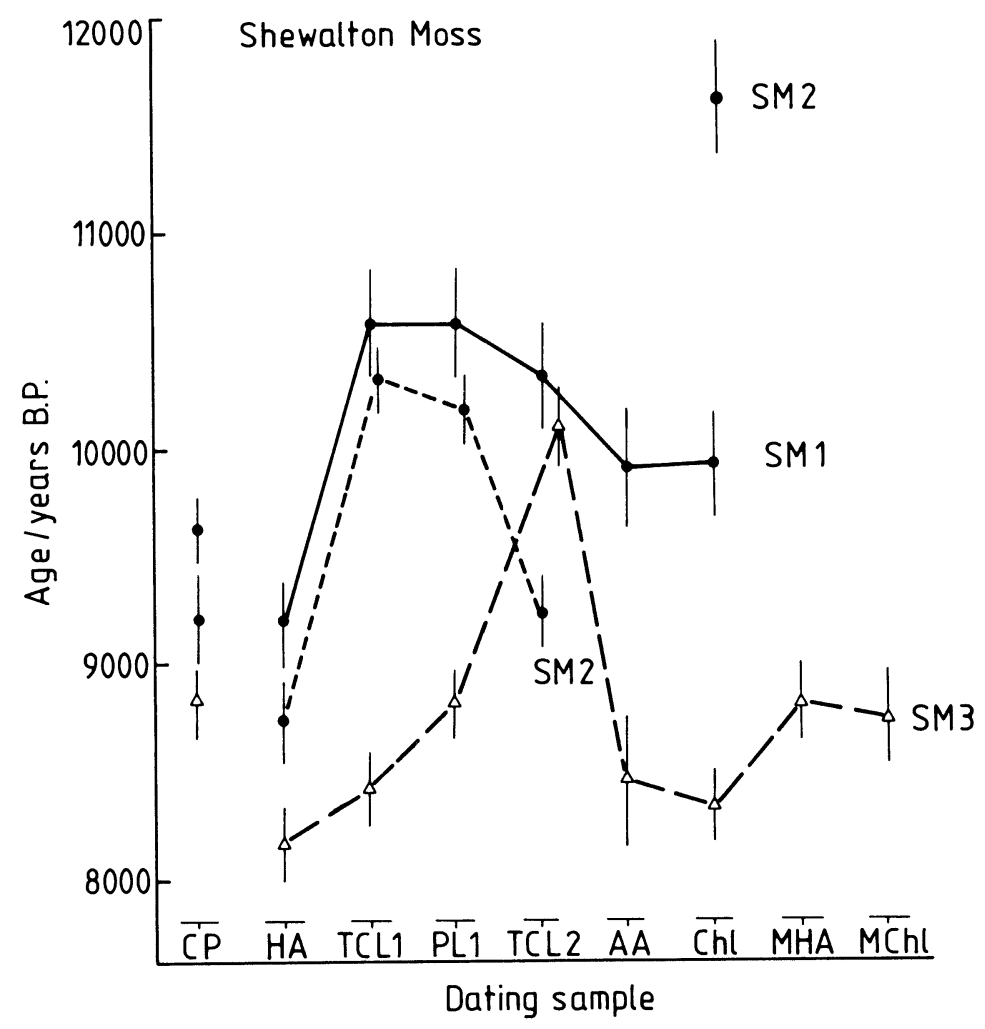

Fig 4. Dates for the various components from different stratigraphic levels of peat sediment from Shewalton Moss. Labels for each component as for Figure 1, and

AA - amino acids

$\mathrm{MCH} 1$-macrofossils after chlorite treatment

MHA-macrofossil humic acid

illustrates a significantly displaced age from the main data set (Fig 4) which is consistent with the mainly algal content of the lipid classes analyzed.

Another example is the first lipid extract of the Svinavatu West site in Iceland, SVW4 (Fig 2). Again, there is a major algal contribution to the sample as determined by lipid analysis. Where identifiable macrofossils are recovered and their ecologic status determined, comparison of the ${ }^{14} \mathrm{C}$ date can confirm the presence or absence of hard-water effects. (In the case of Llyn Gwernan, the dated macrofossils were from Chara, an aquatic plant of calcareous environments, and agreed with the algae-derived lipid dates.)

\section{CONCLUSIONS}

This preliminary survey on a variety of sediments has resulted in the following strategy for the assessment of sediment samples on a routine basis to maximize the useful information return. 
Strategy

It is proposed that, in terms of laboratory time, expense and economy of information, a maximum of five measurements should be made on various sediment preparations:

1) conventional preparation

2) humic acid

3) total crude lipid I

4) macro-fossil cellulose

5) chlorite preparation

Users often require most of their sediment for other analyses, so that the measurement of a conventional preparation on ca $500 \mathrm{mg}$ dry weight sediment would suffice, the "date" interpreted in the light of other environmental data (assessments of possible effects of hard-water and terrestrial inwash).

Whether a 'date' is accepted or not by the user, the decision should always be based on sound supporting evidence. More often than not, the measurement made by a ${ }^{14} \mathrm{C}$ laboratory will represent the sample submitted. If the date is rejected, it implies the ${ }^{14} \mathrm{C}$ age is wrong, but this is misleading. The calculated age will be correct, based on laboratory measurement. What is wrong is the assumption that the measurement can always be expressed as an age. As the results presented here show, components of a sample may have widely differing ages or be quite close in age, depending on the individual sample and its environment. Whether any of the ages relate to the date of deposition must be assessed using other analytical information.

\section{Routine Procedure}

There are several parameters to consider when making the choice as how best to treat a sediment for ${ }^{14} \mathrm{C}$ analysis. The following questions should be answered before starting:

1) How much sample (wet weight) does the user have? sis)?

2) What is the \% organic carbon content of the sample (CHN analy-

3) What is the water content?

4) Are the results likely to be influenced by hard-water error, terrestrial inwash, mineral carbon?

5) What is the expected sedimentation rate?

6) What is the accuracy required of the measurement?

Depending on the answers to the above, the user has the option to do one or both of the following:

a) Make one measurement on the total sediment less carbonate on ca $500 \mathrm{mg}$ dry weight, depending primarily on the organic carbon content;

b) Compare different components of the sedimentary organic matter (conventional preparation, humic acid, total crude lipid I, macrofossil cellulose and chlorite preparation) and perform a lipid analysis.

If the answer to 1 is not limiting the user to option (a), continue. If the answer to 2 is $>2 \%$ organic carbon, the user has up to $10 \mathrm{~cm} \times 4 \mathrm{~cm}$ material deposited over $100 \mathrm{yr}$ or so (ie, quickly), and an accuracy of $\pm 200 \mathrm{yr}$ will 
TABLE 5

Causes of possible errors in ${ }^{14} \mathrm{C}$ dates selected, with other analytical methods, for the best estimate of the time of deposition

\begin{tabular}{|c|c|c|c|c|c|}
\hline \multirow[b]{2}{*}{ Radiocarbon sample } & \multicolumn{5}{|c|}{ Causes of possible errors } \\
\hline & $\begin{array}{l}\text { Hard } \\
\text { water }\end{array}$ & $\begin{array}{c}\text { Mineral } \\
\text { carbon }\end{array}$ & $\begin{array}{l}\text { Modern } \\
\text { microbiological } \\
\text { activity } \\
\text { (low organic } \\
\text { carbon content } \\
\text { samples) }\end{array}$ & $\begin{array}{c}\text { Redeposition } \\
\text { of mobile } \\
\text { humic acid }\end{array}$ & $\begin{array}{l}\text { Old soil } \\
\text { inwash }\end{array}$ \\
\hline $\begin{array}{l}\text { Conventional preparation } \\
\text { (for comparison with } \\
\text { conventional measure- } \\
\text { ments of other laborato- } \\
\text { ries) }\end{array}$ & $\checkmark$ & $\checkmark$ & $\checkmark$ & $\checkmark$ & $\checkmark$ \\
\hline Humic acid & $\checkmark$ & $x$ & $x$ & $\checkmark$ & $\checkmark$ \\
\hline Total crude lipid I & $\checkmark$ & $x$ & $\checkmark$ & $\times$ & $\checkmark$ \\
\hline Chlorite preparation & $\times$ & $\checkmark$ & $\times$ & $\times$ & $\checkmark$ \\
\hline Macrofossil cellulose & $\checkmark$ & $\times$ & $\times$ & $\times$ & $\checkmark$ \\
\hline
\end{tabular}

$x=$ absent for this sample; $\checkmark=$ present for this sample

suffice, go to (b). A $5 \%$ organic carbon content and water of content of $75 \%$ will allow the attainment of (b) for a dry sediment mass of $60 \mathrm{~g}$. This may have to be obtained by bulking samples from several cores. Obviously, the higher the percent organic carbon and the lower the water content, the less wet weight sediment is required. If the answer to 2 is $<2 \%$, go to (a). The answers to 2 and 3 will allow the calculation of the approximate mass of sample required for a single total sediment ${ }^{14} \mathrm{C}$ measurement.

Any macrofossils should be removed from the sample and treated separately. They should also be submitted for species analysis before preparation. If the results are likely to be affected by hard water, etc, this should be remembered when interpreting the results, and every effort made to supply a sample of associated terrestrial macrofossils (though it is possible that the macrofossils may not be contemporary with the event of sedimentation due to old soil inwash). Just before processing the sediment sample, the outer $0.5 \mathrm{~cm}$ should be removed and discarded. Subsequent procedures are as described in the text. Table 5 summarizes the results obtainable from the chosen ${ }^{14} \mathrm{C}$ measurement samples.

REFERENCES

Boon, J J, de Leeuw, J W and Schenck, P A, 1975, Organic geochemistry of Walvis Bay diatomaceons ooze- I. Occurrence and significance of fatty acids: Geochim et Cosmochim Acta, v 39, p $1159-1565$.

Brooks, P W, Fglinton, G, Gaskell, S J, McHugh, I) J, Maxwell, J R and Philp, R P, 1976, Lipids of Recent sediments. Part I: Straight-chain hydrocarbons and carboxylic acids of some temperate lacustrine and subtropical lagoonal/tidal flat sediments: Chem Geol, v 18, p $21-38$.

1977, Lipids of Recent sediments. Part II: Branched and cyclic alkanes and aklanoic acids of some temperature lacustrine and subtropical lagoonal/tidal flat sediments Chem Geol, v 20, p $189-204$

Cranwell, P A, 1973, Chain length distribution of n-alkanes from lake sediments in relation to post-glacial environmental change: Freshwater Biol v 5, p 259-265. - 1974, Moncarboxylic acids in lake sediments: indicators, derived from terrestrial and aquatic biota, of palacoenvironmental trophic levels: Chem Geol, v 4, 1-14. 
Olsson, I U, 1972, A critical analysis of ${ }^{14} \mathrm{C}$ datings of deposits containing little carbon, in Rafter, T A and Grant-Taylor, T, eds, Internatl ${ }^{94} \mathrm{C}$ conf, 8th, Proc: Wellington, Royal Soc New Zealand, p G11-G18.

Scharpenseel, H W, 1979, Soil fraction dating, in Berger, R and Suess, H E, eds, Radiocarbon dating, Internatl ${ }^{14} \mathrm{C}$ conf, 9th, Proc: Berkeley, Univ California Pres, p 277-283.

Schoute, J F Th, Mook, W G and Streuerman, H J, Radiocarbon dating of vegetation horizons, in Mook, W G and Waterbolk, H T, eds, Groningen conf on ${ }^{14} \mathrm{C}$ and archaeology, Proc: PACT, p 295-311.

Sheppard, J C, Syed, Y A, and Mehringer, Jr, P J, 1979, Radiocarbon dating of organic components of sediments and peats, in Berger, $\mathrm{R}$ and Suess, $\mathrm{H}$ E, eds, Radiocarbon dating, Internatl ${ }^{14} \mathrm{C}$ conf, 9th, Proc: Berkeley, Univ California Press, p 284-305. 